\title{
Digital Mediatization in Medicine: New Models of Clinic-to-Doctor-to-Patient Interaction
}

\author{
Marina V. Shutova ${ }^{(1,2)}$, Yana S. Rocheva $(2,3)$ \\ ${ }^{(1)}$ St. Petersburg State University Hospital, \\ 154 Fontanka river embankment, St. Petersburg, 198103, Russian Federation \\ ${ }^{(2)}$ St Petersburg State Electotechnical University (LETI), \\ 5 Prof. Popova St., bldg 5, St. Petersburg, 197376, Russian Federation \\ ${ }^{(3)}$ Federal Scientific Center of Rehabilitation of the Disabled Persons named after \\ G.A. Albrekht, the Ministry of Labor and Social Protection of the Russian Federation \\ 50 Bestuzhevskaya St, St. Petersburg, 195067, Russian Federation
}

$\bowtie$ marbelru@gmail.com

\begin{abstract}
Mediatization is an interdisciplinary construct, which allows us to study how the transformation of social institutions is affected by media influence and social theories. Researchers are focusing on people's digital representations and new interaction models. As digital networks grow and overlap with traditional interaction forms, new models of clinic-doctor-patient interaction emerge. Researching this reveals the efficiency of communicative constructivism. The purpose of the research is to study the transformative effect of mediatization on medicine. The research methodology is based on communicative constructivism and phenomenological approach, including analysis of 70 Instagram accounts of doctors and clinics and in-depth interviews of 10 St. Petersburg-based doctors. The research validates the transformation tendencies in medicine as a social institution.
\end{abstract}

Keywords: mediatization, medicine mediatization, social, medicine, interaction patterns, doctor, patient, clinic

Conflicts of interest. The authors declare that there is no conflict of interest.

Article history: submitted: February 24, 2021; accepted: March 25, 2021.

For citation: Shutova, M.V., \& Rocheva, Y.S. (2021). Digital mediatization in medicine: New models of clinic-to-doctor-to-patient interaction. RUDN Journal of Studies in Literature and Journalism, 26(4), 722-729. doi: 10.22363/2312-9220-2021-26-4-722-729 


\title{
Цифровая медиатизация в медицине: новые модели взаимодействия врач - пациент - клиника
}

\author{
М.В. Шутова ${ }^{(1,2)}$, Я.С. Рочева ${ }^{(3)}$ \\ ${ }^{(1)}$ Санкт-Петербургский государственный университет, \\ Клиника высоких медицинских технологий имени Н.И. Пирогова, \\ Российская Федерачия, 198103, Санкт-Петербург, набережная реки Фонтанки, 154 \\ ${ }^{(2)}$ Санкт-Петербургский государственный электротехнический университет (ЛЭТИ), \\ Российская Федерация, 197022, Санкт-Петербург, ул. Проф. Попова, д. 5 \\ (3) Федеральный научный иентр реабилитации инвалидов \\ имени Г.А. Альбрехта Минтруда России, \\ Российская Федерачия, 195067, Санкт-Петербург, ул. Бестужевская, д. 50 \\ marbelru@gmail.com
}

\begin{abstract}
Аннотация. Междисциплинарный статус концепта медиатизации позволяет рассматривать трансформацию социальных институтов с точки зрения влияния теорий медиа и социальных теорий. Фокус внимания исследователей переносится на цифровые репрезентации и новые практики взаимодействия. Исследование новых моделей взаимодействия врач - пациент - клиника, обусловленных цифровыми коммуникационными сетями, и их пересечение с традиционными формами, показывает практическую полезность социально-конструктивистского подхода. Цель исследования: характеристика влияния социальных медиа, развития цифровых технологий на трансформацию института медицины. Методология исследования основывается на социальноконструктивистском и феноменологическом подходах, включает анализ содержания цифровых репрезентаций отдельных индивидов и организаций и практик их взаимодействия с пациентами. На основании содержательного контент-анализа страниц социальных сетей клиник и врачей (70 аккаунтов сети Instagram), глубинных интервью среди врачей Санкт-Петербурга (10 человек) впервые приводятся доказательства отмеченных тенденций трансформации социального института медицины.
\end{abstract}

Ключевые слова: медиатизация, социальные институты, медицина, паттерны взаимодействия, врач, пациент, клиника, медиатизации медицины

Заявление о конфликте интересов. Авторы заявляют об отсутствии конфликта интересов.

История статьи: поступила в редакцию - 24 февраля 2021 г.; принята к публикации - 25 марта 2021 г.

Для цитирования: Shutova M.V., Rocheva Y.S. Digital mediatization in medicine: New models of clinic-to-doctor-to-patient interaction // Вестник Российского университета дружбы народов. Серия: Литературоведение. Журналистика. 2021. Т. 26. № 4. С. 722-729. doi: 10.22363/2312-9220-2021-26-4-722-729 


\section{Introduction}

Society is undergoing rapid mediatization that is causing social institutions to reformat and recreate themselves. Medicine, among others, is also experiencing a transformation under the influence of digital technologies. Mediatization has already significantly impacted medicine as a social institution. The current changes have to be thoroughly studied along with their implementation mechanisms to enable a humanitarian expert assessment of the novel medicine and avert any possible risks. The role of an individual doctor as an agent of social influence is assuming greater prominence. Given these facts, we need to estimate the implications the changes occurring may have for society as a whole and medicine in particular.

New models of patient-doctor-clinic interaction are emerging. Social media are shifting the focus of patients' attention towards the digital representations of individual personalities. According to J. Baudrillard, neglecting the social structure hierarchy (the so-called 'revamp of the society') has raised the masses to a level not only above the creative minority but also above the social norm that was previously enabled to adjust the behavior of the masses. Without the social component above, the masses have started to dictate their tastes [1]. This entails additional risks for those suffering from diseases and devalues the skill and knowledge of narrow-field specialists in the eyes of the common people. In turn, the social success of blogger doctors does not simply attract the attention of patients but moves the focus of attention of the general public from social institutions (healthcare organizations) and their public representations to specific individuals (doctors), which stimulates medical specialists to further exploit this pattern.

\section{Conceptual approaches of mediatization theory in empiric studies of the transforming social institute of medicine}

The contemporary theory of mediatization can be split into two approaches: the "institutional" approach [2] and the "social constructivist" approach [3, 4]. The first approach suggests that mediatization shapes the development of social processes. According to Hjarvard, the media integrates into the functioning of other social institutions and thereby changes its norms and methods, adapting it to the specifics of media text as a genre and the commercial requirements of the authors (or media owners). A study of digital representations of individuals and social institutions in healthcare [5] showed that in the era of digital media and, in particular, social media as the primary means of communications, personalities elicit far greater interest compared to organizations. An earlier study demonstrated the increasing importance of the doctor in the doctor-patient-clinic interaction model. 
However, the institutional approach does not reveal the true essence of how the media format is influencing the transformations we are witnessing. The social reality is formed by practice - people's joint activity. We interviewed doctors specializing in multiple areas, with blogger doctors whose subscribership exceeded $10 \mathrm{~K}$ among them. These expert interviews showed that doctors get more consultation and treatment requests via social media, such as Instagram and WhatsApp, than they do via official websites of clinics where they are employed, or via review portals. None of the interviewees mentioned that they receive patient requests via specialized internet portals for diseases they expertly treat. These data may suggest that since the subject of health is intimate by nature, patients prefer to communicate with doctors using media that most closely resemble direct interpersonal communication.

\section{Mediatization in medicine: Analysis}

The demand for personalized, individual interaction (or its simulation) between the patient and the generalized 'health-related help provider' is indirectly proven by a comparative study of accounts belonging to blogger doctors and medical organizations on Instagram. 60 Instagram accounts of doctors focused on personal brand promotion and 15 accounts of clinic chains were selected at random. The decision to focus on chain clinics and not independent medical organizations was based on the fact that chains have more promotion resources and often employ a more proactive communications policy compared to independent clinics. The accounts met the following selection conditions: the number of subscribers was over 2000 as of February 1, 2021, and the doctor's (or the chain's) work is geographically based in Russia. The analysis was based on engagement rate (ER), a parameter describing subscriber involvement in the interaction with the author of the media. The mean ER value for clinics was found to be $0.89 \%$ and the values ranged from $0.047 \%$ to $3.93 \%$, while the average ER for doctors was $10.051 \%$, values ranging from $5.5 \%$ to $18.593 \%$. The study also included an analysis of performative utterances by doctors and institutional organizations (i. e. clinics) in the Instagram media space. Since texts are used as a means of interaction with the world outside and the people in it, the truth becomes a matter of speech practice and public discourse [6]. The study showed that clinics mostly use their social media accounts as a channel for direct advertising and the texts they post are more formal. On doctor personal social media account webpages, audience interactions are personalized and emotional. Patients demonstrate by their activities online (i. e. reviews, likes, comments, direct messages) that the emotional aspect of communication is overwhelmingly important to them.

The social constructivist concept paradigm of mediatized worlds developed by F. Krotz and A. Hepp [3; 4] states that every mediatized world has its own 'communicative figuration', and any changes occurring therein should become the 
subject of mediatization studies. This paradigm appears to be better suited for empirical studies of social words from the perspective of mediatization. As Nim E. [7] sums it up, this approach represents "an ambitious project to revise social theory and make it more attuned to the transformative potential of communicative technologies". Following the logic suggested by Hepp, the authors conducted a study comprising 10 expert interviews with practicing doctors to find out about their experience of remote digitized interaction with patients. The focus group included doctors of various specialist fields. The study showed that all the doctors use digital means of interaction with patients. If a doctor promotes themselves on social media, they become a systemically important node and a leader of the subscriber group, regardless of how many of these subscribers are colleagues, patients, or just curious.

The key concepts describing the structure of a communicative figuration in Hepp's view were used as a backbone for the narrative analysis of the expert interviews with doctors. The results helped identify the method of shaping the role identities of the patient and the doctor during their mediatized interaction. They also helped establish how the digital context of the doctor-patient interaction impacts the experience of the interaction.

\section{Actors}

Actors build communication directly, in such a way that the clinic steps out of the limelight and into the background. Under the conditions of mediatization, digital communications doctor-to-patient follow the same patterns as traditional ones. Doctors do not digress substantially from their routine work algorithm in interactions with the patient. Actors build communication in a free manner. The clinic has no way of influencing this interaction. Regardless of whether the clinic offers the service of consultation or not, doctors of all the specialties covered by the study practice remote consultations. "Actually, you can do online consultations in virtually $100 \%$ of cases, ... and so as not to waste the patient's time, you can ... discuss everything, then tell them what they need to do further, and then the patient arrives fully prepared to start inpatient treatment and ready for surgery" (an oncologist surgeon, 7 years of practice).

\section{Forms}

The forms of interacting and establishing initial contact are becoming simpler, the doctor is becoming more "accessible" so the patient can address them directly and take fewer actual steps to do so; regardless, the essence of the interaction and the distribution of roles within it remain unchanged - doctors assume the role of a parent, and patient has to take the role of a kid according to Eric Bern's terminology [8].

Even though direct patient contact is left out of the equation, doctors name quite a few benefits they are gaining. Specifically, they quote time savings, 
interaction conciseness, greater resource efficiency for the patient, and the convenient structure of the interaction. As an expected drawback of online interactions, doctors mentioned the inability to perform a full spectrum of checkups and manipulations on the patient (palpation, auscultation, etc.) when it is required.

Additionally, it should be noted that even doctors with little experience and capacity in remote consulting did not display a total aversion to doing consultations online. "As yet, I don't see how I could apply teleconsulting in my work, but I will perhaps find a way to incorporate it later" (a proctologist, 3 years of practice). This comment is of particular interest because this doctor was the only interviewee who is not currently practicing teleconsultations.

\section{Media}

The media are not inextricably linked to the communications, and the level of trust does not change depending on whether the patient met the doctor via a specialized portal or in a social network. The level of trust the patient has for the doctor depends on the doctor's brand, on how well the doctor is 'remotely familiar' to the patient, and on the doctor's communicative skills. Digital communications have become organically integrated with doctor-patient interactions. Given this, the significance of the doctor's communicative skills and building a professional brand increases since these are the key factors that determine the path of the patient to the doctor. The stronger they are, the shorter and the smoother that path becomes. "They find me via YouTube, Instagram, Facebook, or with the help of my own site or clinic's site, they email to me or to my personal assistant" (a cancer surgeon, 7 years of practice)

\section{Frames of relevance}

The frames of relevance remain unchanged, and mediatization does not affect the role of the doctor. The forms of communication have changed, but media ensembles, means of communication are not crucially important to the doctor. The platform (i. e. the place where digital communication takes place a social network, a messenger, or a video conference) does not influence the structure of communication between the doctor and the patient. The priorities here are the protocol, the plan of work, and the experience of building interactions. "I don't see any conceptual difference in communication comparing online and offline medical advisement" (traumatic surgeon, 16 years of practice)

During the study, not a single medical specialist was found to represent a medical specialty in which remote patient interactions are dismissed as ineffective. All the doctors said that for remote consulting they use messengers (and WhatsApp is the most popular one) and email; for consulting in the video format, they mostly use Zoom or Skype. It is interesting that according to the 
respondents' assessments, the pandemic has neither increased nor decreased the number of remote consultations that they do. The practice of remote consulting was a working routine norm even before the pandemic. The interviewees said they had practiced remote consulting of patients for over 3 years. All the respondents mentioned that it has become easier to engage in the interaction, and the interactions have become more accessible. None, however, mentioned any significant changes in the interaction protocol that the shift online has caused.

\section{Conclusion}

Digital communication has become commonplace even in medicine. Real digital interaction practices by a wide margin exceed the official statistics in terms of volumes. All those involved in the interaction perceive certain benefits from this kind of interaction: time is saved and interaction structure is optimized, all of which works towards achieving the best possible result.

With the approach professed by Couldry and Hepp, it is possible to empirically assess how digital communications are impacting the transformation of medicine as a social institute. In particular, mediatization influences the forms and means of communication while also changing media ensembles. Actors directly build communication. Interaction forms are simplified, and the doctor becomes more readily accessible. Despite the drawbacks of remote (digital) interaction, doctors acknowledge it as highly useful and effective. It is noteworthy that the media are not linked to communication: it is the doctor's brand that defines the level of trust that a patient displays. The frames of relevance remain unchanged. It appears a promising subject for prospective research to assess the impact of mediatization on media ensembles.

The research demonstrates that it can be stated that the mediatization of medicine has become established as a new phenomenon. What is implied by this term is the process of transformation invoked by the emerging digital communication that has given the masses free access to medical information; has caused medical knowledge to lose at least some of its sacral nature; and has pushed the personality of a particular actor to the fore in the context of interaction, with their communicative skills now playing the decisive role.

\section{References / Библиографический список}

[1] Baudrillard, J. (2000). In the Shadow of the Silent Majority, or the End of the Social. Ekaterinburg: Ural University Publishing House. (In Russ.)

Бодрийяр Жан. В тени молчаливого большинства, или Конец социального. Екатеринбург, 2000.

[2] Hjarvard, S. (2013). The Mediatization of Culture and Society. London: Routledge.

[3] Krotz, F. (2009). Mediatization: A concept with which to grasp media and societal change. In Lundby Knut (Ed.), Mediatization: Concept, changes, consequences (pp. 1938). New York: Peter Lang. 
[4] Hepp, A. (2013). The communicative figurations of mediatized worlds: Mediatization research in times of the mediation of everything. European Journal of Communication, 28(6), 615-629. doi: 10.1177/0267323113501148

[5] Shutova, M.V., \& Rocheva, Y.S. (2021). Digital media and new patient-clinic-doctor interaction patterns. Proceedings of the 2021 Communication Strategies in Digital Society Seminar (2021 ComSDS). April 14 (pp. 82-85). doi: 978-0-7381-4529-7/21/ $\$ 31.00$

[6] Rorty, R. (1998). Truth and Progress: Philosophical Papers (Vol. 3, p. 339). Cambridge: Cambridge University Press. doi:10.1017/CBO9780511625404

[7] Nim, E.G. (2017). Exploring the Mediatization of Society: The Concept of Mediatized Worlds. Sociological Journal, 23(3), 8-25. doi: 10.19181/socjour.2017.23.3.5361 (In Russ.)

Ним Е.Г. Исследуя медиатизацию общества: концепт медиатизированных миров // Социологический журнал. 2017. Т. 23. № 3. С. 8-25. doi: 10.19181/socjour.2017. 23.3.5361

[8] Bern, E. (2018). Principles of Group Treatment. Moscow: Academic project. (In Russ.) Берн Э. Групповая психотерапия и трансактный анализ. М.: Академический проект, 2018.

\section{Bio notes:}

Marina V. Shutova, Assistant Professor of the Public Relation Department, St. Petersburg State Electrotechnical University «LETI». ORCID: 0000-0002-0095-773X; e-mail: marbelru@gmail.com

Yana S. Rocheva, $\mathrm{PhD}$ of Sociology Science, Leading Research Associate of the Department the Monitoring Rights of Persons with Disabilities, Federal Scientific Center of Rehabilitation of the Disabled Persons Named after G.A. Albrekht, the Ministry of Labor and Social Protection of the Russian Federation. Assistant Professor of the Public Relation Department, St. Petersburg State Electrotechnical University «LETI». ORCID: 0000-00027162-8917; e-mail: rocheva_yana@mail.ru

\section{Сведения об авторах:}

Шутова Марина Вадимовна, Ассистент кафедры Связи с общественностью гуманитарного факультета СПбГЭТУ (ЛЭТИ). ORCID: 0000-0002-0095-773X; e-mail: marbelru @gmail.com

Рочева Яна Сергеевна, кандидат социологических наук, ведущий научный сотрудник, ФГБУ «Федеральный научный центр реабилитации инвалидов имени Г.А. Альбрехта» Министерства труда и социальной защиты Российской Федерации, доцент кафедры Связи с общественностью гуманитарного факультета СПбГЭТУ (ЛЭТИ). ORCID: 00000002-7162-8917; e-mail: rocheva_yana@mail.ru 